\title{
Khucc tower: from cultural values to practical solutions
}

\author{
Quy Van Khuc
}

(CVietkap team, Hanoi, Vietnam

Version 1.1

Date: February 5, 2021

Preprint DOI: https://osf.io/stbj4
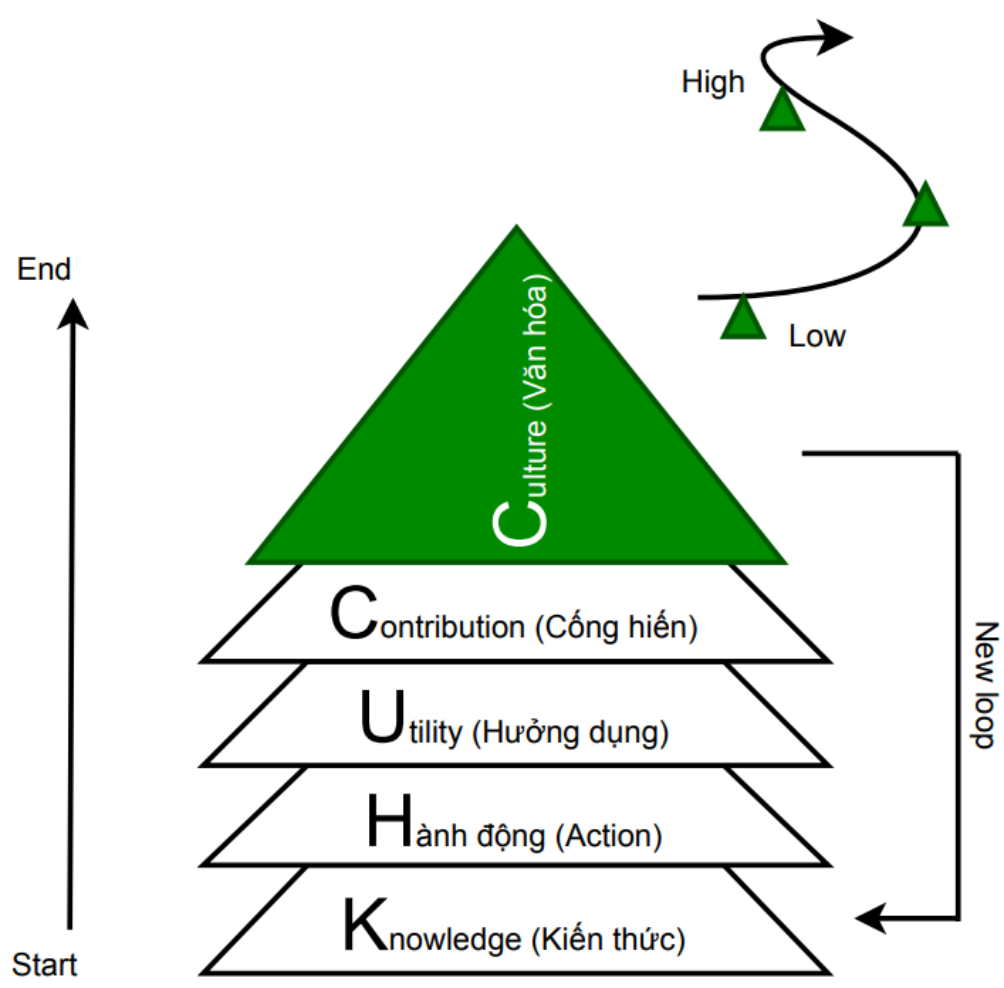

Fig 1. Khucc tower of culture 